\title{
The First World War and the Middle East: A Literature Review of Recent Scholarship
}

Abstract: This article is intended to review the recent scholarship only of the Middle East in that conflict in order to offer some sense of the scale and direction of publications in the field. It covers those publications that have appeared since 2000 rather than established works that were produced before that date.

The centenary of the First World War has produced a fresh wave of publications, ranging from scholarly and detailed articles on previously neglected subjects to popular histories covering the established themes. The fact that this was a global war, and the incidence of recent conflicts, means that a number of works cover the Middle East. There are often attempts to locate the foundations of modern Middle Eastern conflicts in the First World War, which is perhaps understandable, if often inaccurate. There is a set of teleological assumptions for those that try to find the sources of current troubles in 1914-1918, and anachronistic judgements that claim inevitability for subsequent developments, such as the Arab-Israeli conflicts after 1948. Despite this problem, research into the war is healthy, if imbalanced in favour of particular issues. For those trying to navigate their way through recent general scholarship on the First World War, that is, after 2001, one recommendation is to examine Jennifer Keene and Michael Neiberg's edited volume on Finding Common Ground: New Directions in First World War Studies. ${ }^{1}$ Another option is to investigate the various First World War studies research groups, including the 'Globalising and Localising the Great War' research team established at Oxford. This article is intended to review the recent scholarship only of the Middle East in that conflict in order to offer some sense of the scale and direction of publications in the field.

For the policies of the Ottomans in the pre-war period and during the war itself, there are several new publications. Feroz Ahmad has traced the revolutionary period in Ottoman politics and shown how the Young Turks, and their militarised ideology, precipitated their entry into the Great War. ${ }^{2}$ In a series of articles, culminating in his excellent book, Mustapha Aksakal has shown the full range of calculations, and misjudgements, of that political movement. ${ }^{3}$ Aksakal's The Ottoman Road to War in 1914 is a valuable contribution to our understanding of that well-worn subject, the causes of the First World War. Two other works, which feature later in this review, provide equally clear and valuable expositions on the Ottoman Empire's sense of crisis and desire for a decisive resolution, namely the outstanding books by Eugene Rogan on The Fall of the Ottomans and Ryan Gingeras' Fall of the Sultanate. Hans-Lukas Kieser, Kerem Oktem and Maurus's edited volume, World War I and the End of the Ottomans, published in 2015, does not actually focus on the Great War, as it contains chapters predominately on the impact of the Balkan Wars on the Ottoman system. ${ }^{4}$ There is one useful chapter on Palestinian and Jewish loyalties during the conflict, and another on regional variations in the Armenian massacres, but the value of the

\footnotetext{
${ }^{1}$ Jennifer Keene and Michael Neiberg, (eds.) Finding Common Ground: New Directions in First World War Studies. (Leiden, Brill 2011).

${ }^{2}$ Feroz Ahmad, The Young Turks: The Committee of Union and Progress in Turkish Politics, 1908-14. (London: Hurst \& Co., 2010).

${ }^{3}$ Mustapha Aksakal, 'Holy War Made in Germany? Ottoman Origins of the 1914 Jihad', War in History, 18 (2011): 184-199 and 'The Limits of Diplomacy: The Ottoman Empire and the First World War', Foreign Policy Analysis, 7 (2011): 197-203, and The Ottoman Road to War in 1914 (Cambridge, 2008).

${ }^{4}$ Hans-Lukas Kieser, Kerem Oktem and Maurus, (eds.), World War I and the End of the Ottomans, (London: I.B. Tauris, 2015).
} 
work lies in its discussions of Ottomanism before 1914, and its relationship to what the editors call 'violence and viability' rather than the war itself.

The periphery of the Ottoman Empire before the war has also received some scholarly attention. James Onley's excellent article on the role of commerce as a conduit of British influence in Arabia appeared in 2009. ${ }^{5}$ Gokhan Cetinsaya in 2006 published the Ottoman Administration of Iraq, and Sean McMeekin released his book on German ambitions in the region, manifest in the Berlin to Baghdad Railway project. ${ }^{6}$ An especially striking article was Michael Reynolds challenge to the orthodoxy of Pan-Turanian ambitions, as expressed by Enver Pasha, concerning the Caucasus. Reynolds makes a convincing case for pragmatic objectives, not least in establishing a better bargaining position after the war, in explaining the final offensive across the Caucasus in 1918 rather than the usual condemnation of fantasist delusions. ${ }^{7}$

Nevertheless, ideology did have a part to play in Ottoman calculations. Unsurprisingly, a considerable amount of recent literature is focussed on the question of massacres and deportations with the majority of works covering the treatment of the Armenians. Some of the works offer a general survey, such as Alan Kramer's chapter in the volume by John Horne which appeared in $2010 .{ }^{8}$ Others situate the crisis for Armenians in the depressing context of genocides, the best detailed work being offered by Donald Bloxham. ${ }^{9}$ Tamer Akçam has written extensively and in great detail over the last decade on the issue and is in no doubt that the term genocide must be applied. ${ }^{10}$ This is also the case in the edited volume by French scholars Joceline Chabot, Marie-Michèle Doucet, Sylvia Kasparian, and Jean-François Thibault, published in 2017. ${ }^{11}$ Gerald Libaridian offers a survey of Armenian history, for those who wish to know more about the depth of antagonism that led to the massacres of 1915, and Ryan Gingeras places the treatment of Armenians in the context of how other ethnic groups were subjected to mistreatment by the Ottoman regime. ${ }^{12}$ Guenter Lewy published a useful explanation of why the issue is still disputed in Turkey in his work in 2005, while Justin McCarthy, Esat Arslan, Cemalettin Taşkiran and Ömer Turan have written about the Armenian resistance, namely at Van, which many Turks feel has been overlooked as a trigger factor in the events that followed. ${ }^{13}$ Tamer Akçam's studies nevertheless posit that Armenian resistance was dealt with disproportionately and the consequences still constitute one of the worst episodes of mass murder in the conflict. Peter Balakian has examined not only the killings and abuse but also the American response to those events. ${ }^{14}$

The Arabs get a very different treatment in the scholarship of the war and there have been some excellent publications in the last 15 years. Eugene Rogan produced an authoritative yet accessible study of the

\footnotetext{
${ }^{5}$ James Onley, The Arabian Frontiers of the British Raj: Merchants, Rulers and the British in the Nineteenth Century (Oxford: Oxford University Press, 2009).

${ }^{6}$ Gokhan Cetinsaya, Ottoman Administration of Iraq, 1890-1908. (New York: Routledge, 2006); Sean McMeekin, The Berlin-Baghdad Express: The Ottoman Empire and Germany's Bid for World Power. (Cambridge, MA: Harvard University Press, 2010).

${ }^{7}$ Reynolds, Michael A., 'Buffers, Not Brethren: Young Turk Military Policy in the First World War and the Myth of Pan-Turanism', Past and Present, 203 (May 2009): 137-79.

${ }^{8}$ Alan Kramer, 'Combatants and Non-combatants: Atrocities, Massacres, and War Crimes.' in John Horne, (ed.) $A$ Companion to World War I. (Chichester: Wiley-Blackwell, 2010).

${ }^{9}$ Donald Bloxham, The Great Game of Genocide: Imperialism, Nationalism and the Destruction of the Ottoman Armenians (Oxford: Oxford University Press, 2005).

${ }^{10}$ Tamer Akçam, From Empire to Republic: Turkish Nationalism \& the Armenian Question. London: Zed Books, 2004) and A Shameful Act: The Armenian Genocide and the Question of Turkish Responsibility (London: Constable, 2007), and The Young Turks' Crime Against Humanity: The Armenia Genocide and Ethnic Cleansing in the Ottoman Empire (Princeton, 2012). ${ }^{11}$ Joceline Chabot, Marie-Michèle Doucet, Sylvia Kasparian, Jean-François Thibault, (eds), Le génocide des Arméniens : représentations, traces, mémoires (Paris: Presses de l'Université Laval, 2017).

12 Gerald Libaridian, Modern Armenia: People, Nation, State. (New York: Transaction Publishers, 2007); Ryan Gingeras, Sorrowful Shores: Violence, Ethnicity and the End of the Ottoman Empire (Oxford: Oxford University Press, 2009).

${ }^{13}$ Guenter Lewy, The Armenian Massacres in Ottoman Turkey: A Disputed Genocide. (Salt Lake City: University of Utah Press, 2005); Justin McCarthy, Esat Arslan, Cemalettin Taşkiran and Ömer Turan, The Armenian Rebellion at Van (Salt Lake City: University of Utah Press, 2006).

${ }^{14}$ Peter Balakian, The Burning Tigris: The Armenian Genocide and America's Response. (New York: HarperCollins, 2003).
} 
Arabs in 2009, but his Fall of the Ottomans (2015), which deals particularly with the war and the fate of the Arabs within it, was very well-received. ${ }^{15}$ The outstanding scholar Charles Tripp added to his stable of valuable works with a history of Iraq in 2007 and a longer survey of resistance in the Middle East in 2013. ${ }^{16}$ To this should be added the more specific, but longitudinal study of Basra and southern Iraq by Reidar Visser. ${ }^{17}$ Two studies of southern Iraq in the First World War are Thair Karim's chapter on 'Tribes and Nationalism' and Mohammad Gholi Majd's general survey published in 2006.18

The British policies towards the Arabs during the war attract perennial interest. James Barr's accessible $A$ Line in the Sand in 2011 was a competent study of the various agreements from 1915 onwards, which exposed the bitter rivalry of Britain and France that jeopardised a settlement of the region. ${ }^{19} \mathrm{His}$ conclusion, that France had actively assisted Jewish resistance against the British in 1947 as retribution for British encouragement to independence in Arabia, including Syria, was startling and persuasive, but his early chapters on the First World War are equally vivid. Two scholarly publications offered useful insights into the calculations and challenges facing the British as they tried to create viable states in place of the Ottoman Empire. Toby Dodge wrote Inventing Iraq in 2003, the year of the Western Coalition invasion of that country to oust Saddam, while Isaiah Friedman gave a critical appraisal of British Pan-Arab Policy at the end of that intervention in 2010.20 Another scholar taking the long view was Phebe Marr, with her Modern History of Iraq. ${ }^{21}$ Not all studies of the region or the period are a success and a truly dire example is Shareen Blair Brysac and Karl Meyer's Kingmakers: The Invention of the Modern Middle East published in 2008. ${ }^{22}$ Populist and inaccurate studies like these propagate the orthodoxy of British 'betrayal' without acknowledging the steps towards independence, wartime support for Arab allies and partners, or sincerity of benign intent that characterised the majority of British officials dealing with a complex region.

Syria was a particular problem in Anglo-French-Arab relations during the war, but new studies have emerged which take us beyond the high politics of the Western Allies. M. Talha Çiçek examines the wartime governance of Djemal Pasha and its influence, a subject also dealt with in a chapter by Najwa alQattan. ${ }^{23}$ There are also two works that examine the origins of nation sentiment in a deeply divided country, namely Adel Beshara's edited volume and Sami Moubayed's focus on influential Syrians. ${ }^{24}$

Arab leadership has also attracted some interest. Ali A. Allawi argues in Faisal I of Iraq (2014) that his subject should be regarded as 'the Great', but the claim is a bold one that tries to overturn the reputation of a deeply flawed and troubled personality. ${ }^{25}$ Laila Parsons has produced an interesting biography of

\footnotetext{
${ }^{15}$ Eugene Rogan, The Arabs: A History (London: Allen Lane, 2009); Eugene Rogan, Fall of the Ottomans (New York: Basic Books, 2015).

${ }^{16}$ Charles Tripp, A History of Iraq (Cambridge: Cambridge University Press, 2007); Charles Tripp, The Power and the People: Paths of Resistance in the Middle East (Cambridge: Cambridge University Press, 2013).

${ }^{17}$ Reidar Visser, Basra: The Failed Gulf State: Separatism and Nationalism in Southern Iraq. (Munster: Lit Verlag, 2005).

${ }^{18}$ Thair Karim, 'Tribes and Nationalism: Tribal Political Culture and Behaviour in Iraq, 1914-1920' in Faleh AbdulJabar and Hosham Dawod, (eds.), Tribes and Power: Nationalism and Ethnicity in the Middle East (London: Saqi books, 2003); Mohammad Gholi Majd, Iraq in World War I: From Ottoman Rule to British Conquest. (Lanham, MD: University Press of America, 2006).

${ }^{19}$ James Barr, A Line in the Sand: Britain, France and the Struggle that Shaped the Middle East (London: Simon \& Schuster, 2011).

20 Toby Dodge, Inventing Iraq: The Failure of Nation-Building and a History Denied. (London: Hurst \& Co., 2003); Isaiah Friedman, British Pan-Arab Policy 1915-1922: A Critical Appraisal. (New Brunswick: Transaction Publishers, 2010).

${ }^{21}$ Phebe Marr, The Modern History of Iraq. (Boulder, CO: Westview Press, 2005).

${ }^{22}$ Shareen Blair Brysac and Karl Meyer, Kingmakers: The Invention of the Modern Middle East. (New York, NY: W.W. Norton \& Company, 2008).

${ }^{23}$ M. Talha Çiçek, War and State Formation in Syria: Cemal Pasha's Governorate during World War I, 1914-1917 (London: Routledge, 2014); Najwa al-Qattan, 'Safarbarlik: Ottoman Syria and the Great War' in Thomas Philipp and Christopher Schuman, (eds), From the Syrian Land to the States of Syria and Lebanon (Beirut: Orient-Institut, 2004): 163174.

${ }^{24}$ Adel Beshara, (ed.), The Origins of Syrian Nationhood: Histories, Pioneers and Identity (CRC Press, 2012); Sami

Moubayed, Steel \& Silk: Men and Women Who Shaped Syria 1900-2000 (Seattle: Cune Press, 2006).

${ }^{25}$ Ali A. Allawi, Faisal I of Iraq (New Haven, CT.: Yale University Press, 2014).
} 
Fawzi al Qawuji, an Ottoman officer who fought in Mesopotamia and Palestine, and went on to lead an insurgency against the French in Syria in the 1920s and then the 1936 revolt against the British Mandate authorities. ${ }^{26}$ His loyalty to the Ottoman Army was unshaken despite increasing Turkish distrust, his arrest, and executions of Arab nationalists. When captured by the Australians, he escaped and rejoined the Ottoman forces rather than defecting to the Sherifian forces, regarding 'Lawrence's Arabs' as just another colonial unit fielded by the British. Later in his career, Qawuji aligned himself to the Germans in the misguided hope of Nazi support for Arab liberation, before returning to lead the disastrous Arab effort against the nascent state of Israel in 1948. The fighting Arab, who turns from loyal Ottoman service to a contrasting national one, this time on the side of the Sherif, is the subject of the publication of Jafar al-Askari, A Soldier's Story in 2003. ${ }^{27}$ The context of his life is provided by Eugene Rogan and Ryan Gingeras in their respective works, which, by far, are the highlight of recent publications in this field.

Rogan and Gingeras have been able to explain, with erudition and rigorous scholarship, the direction of the war, placing the operational histories in their strategic or political context. ${ }^{28}$ Both authors trace the decisions of the Ottoman elites, and the consequences for the subjects of the empire. Rogan's The Fall of the Ottomans, is an outstanding work which attracted praise from leading scholars. He explains deftly the power struggle of 1908-1914 which leads to the creation of the CUP triumvirate, the failure of the early offensives against the Entente, the desperate nature of the defence of Gallipoli, and the long retreat of 1916-1918, and eventual defeat. Gingeras, like Rogan, is interested in the internal effects of the war on the Ottoman Empire, and he explains with great clarity through original source material, the reactions of various Ottoman communities, their leaders, and individuals. ${ }^{29}$ An overview of the entire region and the war appeared in Kristian Coates Ulrichsen's The First World War in the Middle East. ${ }^{30}$ Ulrichsen also produced a volume on the economy and logistics of the war, primarily on the Allied side, while Sevket Pamuk produced a useful chapter specifically on 'The Ottoman Economy in World War I' in Stephen Broadberry and Mark Harrison's edited volume on the economics of the war in 2009.31

Rob Johnson examined the military strategy and operations in his 2016 publication The Great War and the Middle East, situating the fighting against theoretical ideas of strategy and the practical dynamics of war. ${ }^{32}$ The various operational fronts were the subject of a number of studies, and, as in previous decades, the majority of these are ranked in order of popularity rather than significance. It is striking that the largest group of works is typically on Gallipoli and the Dardanelles, followed by Palestine, and then, some way behind, Mesopotamia. Relatively few publications, by comparison, are produced on the Caucasus Front or on Persia, despite the wartime importance of these theatres to the Ottoman Empire. It is striking that there hasn't been a significant volume on the Caucasus Front, and its links to northern Persia, since the 1950s. Johnson's volume reconstructs the strategic calculations of both sides, the manner in which operational outcomes affected the strategy, and the wartime context of the political agreements and treaties drawn up to govern the Middle East thereafter.

The Egyptian Expeditionary Force (EEF) and the operations in Palestine are the subject in Matthew Hughes recent work, and particularly the military leadership of General Sir Edmund Allenby. ${ }^{33}$ Hughes'

${ }^{26}$ Laila Parsons, The Commander, (London: Saqi, 2017).

${ }^{27}$ W. Facey and N.F. Safwat, (eds.), A Soldier's Story: From Ottoman Rule to Independent Iraq; The Memoirs of Jafar alAskari, (London: Arabian Publishing, 2003).

${ }^{28}$ Eugene Rogan, The Fall of the Ottomans: The Great War in the Middle East (New York: Basic Books, 2015).

${ }^{29}$ Ryan Gingeras, Fall of the Sultanate: The Great War and the End of the Ottoman Empire 1908-1922 (Oxford: Oxford University Press, 2017).

${ }^{30}$ Kristian Coates Ulrichsen, The First World War in the Middle East. (London: Hurst, 2009).

${ }^{31}$ Kristian Coates Ulrichsen, The Logistics and Politics of the British Campaigns in the Middle East, 1914-22. (Basingstoke: Palgrave Macmillan, 2010); Sevket Pamuk, 'The Ottoman Economy in World War I' in Stephen Broadberry and Mark Harrison, (eds.), The Economics of World War I (Cambridge: Cambridge University Press, 2009).

32 Rob Johnson, The Great W ar and the Middle East (Oxford: Oxford University Press, 2016).

${ }^{33}$ Matthew Hughes, 'Command, Strategy and the Battle for Palestine, 1917' in Ian Beckett, (ed.) 1917: Beyond the

Western Front. (Leiden: Brill, 2009). 
edited volume of Allenby's correspondence is of particular value to historians. ${ }^{34}$ An excellent study of the morale of the EEF, its shift to a predominantly Indian composition and the army's operational fortunes was James Kitchen's book based on his Oxford DPhil, published in 2014. ${ }^{35}$ A less detailed work on the EEF was produced by Eran Dolev in 2007, while Michael Mortlock and David Woodward produced more narrative histories on the Palestine operations. ${ }^{36}$ John Peaty has also written recently on Palestine in John Wilson's edited volume commissioned by the British Army entitled Forgotten Fronts. ${ }^{37}$ The Ottoman army's experiences on this front appeared most strikingly in a chapter by Tilman Lüdke in 2014 and complement other studies of the Ottoman forces, the incidence of disease and the causes of their defeat. ${ }^{38}$

Operations in Mesopotamia were the subject of Charles Townshend's 2010 volume When God Made Hell: The British Invasion of Mesopotamia and the Creation of Iraq. ${ }^{39}$ His eye for detail and his long experience in tackling the British Army's colonial operations make this the most successful work on the subject for many years. A shorter study was produced by Kristian Coates Ulrichsen in an article for the Journal of Strategic Studies in 2007 while Andrew Syk concentrated on the 1917 Commission on the early setbacks in this campaign, contrasting it with the then on-going Iraq Enquiry. ${ }^{40}$ Syk's doctoral thesis was on the changes in organisation and command from 1916, evaluating the more successful model brought in by General Sir Stanley Maude. At the popular end of the market was Ron Wilcox's narrative history of the operations on the Tigris. ${ }^{41}$ Kaushik Roy, a specialist on the Indian Army, produced an excellent chapter on tactical developments which was both authoritative and accessible. ${ }^{42}$

Gallipoli attracts considerable interest and the approaching anniversary of the campaign in 2015 produced a crop of publications. There were a number of volumes on the Ottoman and Turkish perspectives. Edward Erickson, who possesses a firm knowledge of the tactics of the period, has produced several works but the most recent include Gallipoli: The Ottoman Campaign (2010) and the more contextualised The History of World War I: Gallipoli and the Middle East, 1914-1918: From the Dardanelles to Mesopotamia (2008).43 Robert Johnson and Metin Gurcan edited a volume of Turkish scholars' views of the campaign, including naval operations, propaganda and the use of the history of the war for modern political purposes in Gallipoli: The Turkish Perspective. ${ }^{44}$ Haluk Oral also produced a single-authored publication, Gallipoli 1915 Through Turkish Eyes in 2012.45 Turkish studies of the campaign don't always reach Western audiences

\footnotetext{
${ }^{34}$ Matthew Hughes, Allenby in Palestine: The Middle East Correspondence of Field Marshal Viscount Allenby June 1917 October 1919. (Stroud: Sutton Publishing, 2004).

${ }^{35}$ James Kitchen, The British Imperial Army in the Middle East: Morale and Military Identity in the Sinai and Palestine Campaigns, 1916-1918 (London: Bloomsbury, 2014).

${ }^{36}$ Eran Dolev, Allenby's Military Machine: Life and Death in World War I Palestine (London: I.B. Tauris, 2007); Michael Mortlock, The Egyptian Expeditionary Force in World War I (Jeffereson NC: McFarland, 2011); David R. Woodward, Hell in the Holy Land: World War I in the Middle East (Lexington: University of Kentucky, 2006).

${ }^{37}$ John Wilson, (ed.), Battlefield Guide, vol 2: The Forgotten Fronts (Andover: Army Headquarters, 2016). See also Robert Johnson, 'Mesopotamia', in the same volume.

${ }^{38}$ Tilman Lüdke, 'Loyalty, Indifference, Treason: The Ottoman-German Experience in Palestine During World War I' in Yigal Sheffy and Haim Goren Eran Dolev (eds.), Palestine and World War I: Grand Strategy, Military Tactics and Culture in War (London, I.B Tauris, 2014).

${ }^{39}$ Charles Townshend, When God Made Hell: The British Invasion of Mesopotamia and the Creation of Iraq, 1914-1921.

(London: Faber \& Faber, 2010).

${ }^{40}$ Kristian Coates Ulrichsen, 'The British Occupation of Mesopotamia, 1914-1922.' Journal of Strategic Studies, 30 (2007); Andrew Syk, ‘The Mesopotamia Commission: Britain’s First Iraq Inquiry’, RUSI Journal, 154(4) (2009): 94 101.

${ }^{41}$ Ron Wilcox, Battles on the Tigris (Barnsley: Pen and Sword, 2006).

${ }^{42}$ Kaushik Roy, 'The Army in India in Mesopotamia from 1916-1918: Tactics, Technology and Logistics

Reconsidered' in I. W. F. Beckett (ed.), 1917: Beyond the Western Front (Leiden and Boston: Brill, 2009), pp. 131-58.

${ }^{43}$ Edward Erickson, Gallipoli: The Ottoman Campaign. (Barnsley: Pen \& Sword, 2010); Edward Erickson, The History of World War I: Gallipoli and the Middle East, 1914-1918: From the Dardanelles to Mesopotamia. (London: Amber Books, 2008).

${ }^{44}$ Robert Johnson and Metin Gurcan, (eds.), Gallipoli: The Turkish Perspective (London: Ashgate, 2015).

${ }^{45}$ Haluk Oral, Gallipoli 1915 Through Turkish Eyes (Istanbul: Bahcesehir University Press, 2012).
} 
because they do not get translated, but two works represent the primary interests in Turkey in individuals' responses to the campaign and in the defence of Straits against naval attack. These can be found in, respectively, Selahattin Adil, Canakkale Cephesinden Mektuplar-Haturalar (2007) and in Maurice Larcher, Mehmed Emin Bey, and Murat Çulcu, Çanakkale 1915-Boğaz. Harekâtı (2008).46

In the Anglophone world, the popular historian, Peter Hart, produced a scathing condemnation of British leadership in his volume of $2011 .{ }^{47}$ Such books don't really tell us much about the campaign that is new, and more authoritative studies have been written by Tim Travers. ${ }^{48}$ His succinct but excellent book of the campaign appeared in 2001 but he has also covered Ottoman decision-making during the operations. The late Jeffrey Gray had written on the Australian part in the campaign, putting right many of the myths that have developed in the hundred years since the fighting, while Glyn Harper focussed on a more critical assessment through the correspondence of New Zealand soldiers. ${ }^{49}$ While the ANZAC contribution to the campaign is well-known, far less is written about the Indian Army on the peninsula and it was therefore welcome to see Gordon Corrigan write a chapter on the Gurkhas at Gallipoli. ${ }^{50}$ The part played by Mustapha Kemal in the campaign has become the subject of intense and bitter dispute in Turkey in recent years, but lifting his legacy out of the context of current Turkish politics is Ryan Gingeras' volume Heir to the Empire: Mustafa Kemal Ataturk published in 2015.51

The Caucasus Front is subject to far less scrutiny than other campaign theatres, so it is valuable to have Kamalmadhar Ahmad's Kurdistan during the First World War, published in 2001, and Fevzi Çakmak's Büyüle Harp'te Şark Cephesi Harekatı [untranslated, Operations on the Eastern Front of the Great War] which came out in $2011 .{ }^{52}$

Persia's fate was closely connected to the Caucasus operations, despite its attempts to remain neutral. Ottoman formations invaded, Ottoman and German agents provocateurs tried to disrupt British influence in southern Persia, and Russian troops made their way to Tehran and onto the border with Mesopotamia. Some of the effects of these incidents are reflected in Touraj Atabaki's work of 2006, although there is a characteristic focus on Iranian internal politics here. ${ }^{53} \mathrm{~A}$ rather less successful volume is Mohammed Gholi Majd's attempt to claim that Persia was subjected to a genocide because of the war, confusing poor governance and catastrophic wartime shortages, which led to famine, with the fiction of an intent to wipe out the Persians. ${ }^{54}$

Cultural and religious history connected to the war features in a number of works over the last decade. Dina Rizk Khoury wrote an interesting chapter on Iraqi poetry which conveys the paradoxes of identity and history, while Fanar Haddad offered a less nuanced study of sectarianism in Iraq. ${ }^{55}$ Sectarianism also

\footnotetext{
${ }^{46}$ Selahattin Adil, Canakkale Cephesinden Mektuplar-Hattralar (Letters and Memorabilia from the Chanakkale Front)(Istanbul: Yeditepe Yayinevi, 2007); Maurice Larcher, Mehmed Emin Bey, and Murat Çulcu, Canakekale 1915 Boğaz. Harekâtı (Chanakkale: Operations at the Narrows) (Istanbul: E Yayınları, 2008).

47 Peter Hart, Gallipoli. (London: Profile Books, 2011).

48 Tim Travers, Gallipoli, 1915 (Stroud: Tempus, 2001); Tim Travers, 'The Other Side of the Hill', Military History Quarterly, 12(3) (2000); Tim Travers, 'The Ottoman Crisis of May 1915 at Gallipoli', War in History, 8(1) (2001)

${ }^{49}$ Jeffrey Gray, A Military History of Australia, 3rd edn., (Cambridge, 2008); Glyn Harper, (ed), Letters from Gallipoli: New Zealand Soldiers Write Home (Auckland: Auckland University Press, 2011).

${ }^{50}$ Gordon Corrigan, 'The Gurkhas at Gallipoli' in Rob Johnson (ed.), The British Indian Army: Virtue and Necessity (Cambridge: Cambridge Scholars Publishing, 2014).

${ }^{51}$ Ryan Gingeras, Heir to the Empire: Mustafa Kemal Ataturk (2015).

${ }^{52}$ Kamalmadhar Ahmad, translated by Robert Burton and Ali Maher Ibrahim, Kurdistan during the First World War (London: Saqi Books, 2001); Fevzi Çakmak, Büyülk Harp’te Sark Cephesi Harekatı (Operations on the Eastern Front of the Great War) Istanbul: Türkiye Iş Bankasi Kültür Yayınları, 2011).

${ }^{53}$ Touraj Atabaki, Iran and the First World War: Battleground of the Great Powers (London: I. B. Tauris, 2006).

${ }^{54}$ Mohammed Gholi Majd, The Great Famine and Genocide in Persia, 1917-1919 (Lanham, MA: University Press of America, 2003).

${ }^{55}$ Dina Rizk Khoury, 'Ambiguities of the Modern: The Great War in Memoirs and Poetry of the Iraqis' in Heike Liebau et al, (eds), The World in World Wars: Experiences, Perceptions and Perspectives from Africa and Asia (Leiden and
} 
featured in the study of the Gulf in this period by Laurence Louer. ${ }^{56} \mathrm{~A}$ fascinating survey of minorities, particularly the Assyrian Christians of Iraq and Syria, was the subject of the work by Bulent Özdemir in 2012. ${ }^{57}$ Cultural histories and issues of identity have also been the subject of Ottoman studies, with Erol Köroğlu on Ottoman propaganda (2007), Ian Lyster's edited work on Ottoman-Turkish diaries (2010), and Michael Reynolds rather clumsily titled but general survey of social and economic collapse in 2011.58 Fascinating work was produced by Stefan Goebal on the influence of medieval iconography in the war (and after), in the study of soldier's experiences of Egypt in M. Ruiz's article of 2009 and Abigail Jacobson's volume on Jerusalem in this period. ${ }^{59}$

Technology and tactics are subjects that have produced equally engaging interest. Wilfred Nunn's riverine war on the Tigris was re-issued in 2007 to address again a neglected subject. ${ }^{60}$ The same year Jean Bou examined the use of cavalry in the Palestine campaign, explaining the counter-intuitive decision to return mounted infantry formations to sword-wielding cavalry. ${ }^{61}$ Ottoman technology is assessed in an article in the Journal of Military History from 2002, while Yigal Sheffy reviewed the Allied use of poison gas in the Gaza operations in another article for the same journal in 2009. ${ }^{62}$ Tactical and operation lessons from Mesopotamia were the subject of an interesting article by Youssef Aboul-Enein. ${ }^{63}$

The resilience of the Ottoman Army, and its eventual defeat, has been featured in several recent works, and three are outstanding. Hikmet Özdemir's The Ottoman Army, 1914-1918: Disease and Death on the Battlefield was translated from Turkish in 2008, and the level of statistical detail in the volume is extremely valuable. ${ }^{64}$ Ulrich Trumpener produced a useful chapter on the Ottoman Army in John Horne's edited study published in 2010. ${ }^{65}$ Mesut Uyar published an excellent account of Ottoman officers' changing identity and loyalties in this catastrophic period in an article in 2013, complementing his other work. ${ }^{66}$

The difficulties in obtaining intelligence on the Ottoman forces are the feature of Paula Mohs' work, with reference to the Arab Revolt, but other studies of intelligence in this region are often more concerned with structures, interpretations and effects, such as Martin Thomas's truly excellent Empires of Intelligence and Satia Priya's more idiosyncratic and less persuasive Spies in Arabia. ${ }^{67}$ A biography of Sir

Boston: Brill, 2010): 313-40; Fanar Haddad, Sectarianism in Iraq: Antagonistic Visions of Unity. (New York: Columbia University Press, 2011).

${ }^{56}$ Laurence Louer, Transnational Shia Politics: Religious and Political Networks in the Gulf. (London: Hurst \& Co. 2008).

${ }^{57}$ Bulent Özdemir, Assyrian Identity and the Great War: Nestorian, Chaldean and Syrian Christians in the Twentieth Century (Dubeath: Whittles, 2012).

${ }^{58}$ Erol Köroğlu, Ottoman Propaganda and Turkish Identity: Literature in Turkey during World War I (London: I.B. Tauris, 2007); Ian Lyster, (ed), Among the Ottomans: Diaries from Turkey in World War I (London: I.B. Tauris, 2010); Michael Reynolds, Shattering Empires: The Clash and Collapse of the Ottoman and Russian Empires, 1908-1918 (Cambridge, 2011).

${ }^{59}$ Stefan Goebal, The Great War and Medieval Memory: War, Remembrance and Medievalism in Britain and Germany, $1914-$ 1940 (Cambridge: Cambridge University Press 2007); M.M. Ruiz, 'Manly Spectacles and Imperial Soldiers in Wartime Egypt, 1914-1919.' Middle Eastern Studies, 45 (2009); Abigail Jacobson, From Empire to Empire: Jerusalem between Ottoman and British Rule (Syracuse: Syracuse University Press, 2011).

${ }^{60}$ Wilfred Nunn, Tigris Gunboats: The Forgotten War in Iraq 1914-1917. (London: Chatham Publishing, 2007).

${ }^{61}$ Jean Bou, 'Cavalry, Firepower, and Swords: The Australian Light Horse and the Tactical Lessons of Cavalry Operations in Palestine, 1916-1918. Journal of Military History, 71, (2007).

62 J. Grant, 'The Sword of the Sultan: Ottoman Arms Imports, 1854-1914', Journal of Military History, 66 (2002): 9-36; Yigal Sheffy, 'Chemical Warfare and the Palestine Campaign, 1916-1918.' Journal of Military History, 73 (2009).

${ }^{63}$ L. C. D. R. Youssef Aboul-Enein, 'The First World War Mesopotamian Campaigns: Military Lessons on Iraqi Ground Warfare', Strategic Insights, 4(6) (2005).

${ }^{64}$ Hikmet Özdemir, The Ottoman Army, 1914-1918: Disease and Death on the Battlefield (orig. pub. in Turkish, 2005; Salt Lake City: University of Utah Press, 2008).

${ }^{65}$ Ulrich Trumpener, 'The Turkish War, 1914-1918' in John Horne, (ed.), A Companion to World War I. (Chichester: Wiley-Blackwell, 2010).

${ }^{66}$ Mesut Uyar, 'Ottoman Arab Officers between Nationalism and Loyalty during the First World War', War in History 20, 4 (2013): 526-44.

${ }^{67}$ Paula Mohs, British Intelligence and the Arab Revolt: The First Modern Intelligence War. (London: Routledge 2008); Martin Thomas, Empires of Intelligence: Security Services and Colonial Disorder after 1914 (Berkeley, LA: University of California 
Percy Sykes, who raised the South Persia Rifles, was the subject of Antony Wynn's excellent Persia in the Great Game in 2003.68

Studies of intelligence and irregular warfare are dominated by T.E. Lawrence 'of Arabia'. Scott Anderson took a biographical approach in his 2014 Lawrence in Arabia, while James Barr's Setting the Desert on Fire gave a vivid retelling of the story of the revolt and Lawrence's part in it. ${ }^{69}$ Malcolm Brown's volume that published Lawrence's letters is a useful source in revealing his contemporary thoughts and observations, rather than the better-known version he created in his 1935 Seven Pillars of Wisdom. ${ }^{70}$ Kim McQuaid offered a comparison of the Venezuelan freebooter Rafael de Nogales and T.E. Lawrence in The Real and Assumed Personalities of Famous Men. ${ }^{71}$ The popular market of military history was served by the illustrated Osprey volume by David Murphy, The Arab Revolt 1916-1918, but Gideon Biger published 'The Turkish Activities in Palestine During World War I Revised' to challenge the usual narratives of the Arab Revolt. ${ }^{72}$

Finally, the war time diplomacy, and its aftermath, is the subject of David Fieldhouse's excoriating survey, although the theme appears in several of the volumes already mentioned in this article. ${ }^{73}$ Christopher Catherwood examined the thought processes that led to the creation of Iraq in his book of 2004, arguing that a combination of T.E. Lawrence's persuasion and Winston Churchill's search for a viable state asserted themselves over Arab division. ${ }^{74}$ Like many books on Iraq, this was published in light of the invasion in 2003, and so the history is affected by a desire to posit an agenda that past events sharped, directly, the present. Works of this nature are often subject to subsequent revision. Satia Priya situated the same theme, the creation of Iraq, in article on imperial objectives in 2007. ${ }^{75}$ John Townshend's successful biographical study of Sir Percy Cox gives a vivid impression of both the man and the period..$^{76}$ Johnathan Schneer produced a volume on the Balfour Declaration in 2010, but it is likely that more will follow in this centenary year. Indeed, it seems likely that the four years of anniversary events will generate many more studies, and it can be anticipated that a number of these will tackle the issues of statehood, borders and international jurisdiction that followed the war. ${ }^{77}$

This article is by no means exhaustive and some works have been omitted. There are, in addition, a number of established works, that date back before 2000, which do not feature here but which stand the test of time. The purpose of the article is only to highlight those studies which appear after that date, and the extent of these indicates that the First World War in the Middle continues to generate considerable scholarly interest. Nevertheless, there remain a number of areas which have not been studied very extensively, but will eventually, one hopes, be the subject of research and publications. Biographies of certain actors in this field, particularly on the Ottoman side, would be especially welcome. Minorities and their allegiances would also be an important area of study, while inter-Arab rivalries that were played out during the war need much more attention. Nevertheless, the subject is in rude health and continues to

Press, 2008); Satia Priya, Spies in Arabia: The Great War and the Cultural Foundations of Britain's Covert Empire in the Middle East (Oxford, 2008).

68 Antony Wynn, Persia in the Great Game: Sir Percy Sykes: Explorer, Consul, Soldier, Spy (London: John Murray, 2003).

${ }^{69}$ Scott Anderson, Lawrence in Arabia: War, Deceit, Imperial Folly and the Making of the Modern Middle East (London:

Atlantic Books, 2014); James Barr, Setting the Desert on Fire: T.E. Lawrence and Britain's Secret War in Arabia, 1916-1918 (New York: W.W. Norton, 2008).

70 Malcolm Brown, (ed.), Lawrence of Arabia: The Selected Letters (London: 2005).

${ }^{71} \mathrm{Kim}$ McQuaid, The Real and Assumed Personalities of Famous Men: Rafael de Nogales, T.E. Lawrence and the Birth of the Modern Era, 1914-1937 (London: Gomides Institute, 2010).

72 David Murphy, The Arab Revolt 1916-1918. (London: Osprey Publishing, 2008); Gideon Biger, 'The Turkish Activities in Palestine During World War I Revised' in Yigal Sheffy and Shlaul Shai, (eds.), The First World War: Middle Eastern Perspective. (Tel Aviv, 2000).

${ }^{73}$ D. K. Fieldhouse, Western Imperialism in the Middle East, 1914-1958 (Oxford: Oxford University Press, 2006).

${ }^{74}$ C. Catherwood, Winston's Folly: Imperialism and the Creation of Modern Iraq (London: Constable, 2004).

${ }^{75}$ Satia Priya, 'Developing Iraq: Britain, India and the Redemption of Empire and Technology in the First World War', Past and Present, 197, 1 (2007): 211-55.

${ }^{76}$ John Townshend, Proconsul to the Middle East: Sir Percy Cox and the End of Empire (London: I.B. Tauris, 2010).

${ }^{77}$ Jonathan Schneer, The Balfour Declaration (New York: Random House, 2010). 
attract first class scholars across the world, which must surely be a necessary requirement to confront the deceits of certain violent groups who would otherwise seek to distort the past for their own political ends. 